\title{
Understanding the Dynamics of Return: The Importance of Microfoundations
}

\author{
Inmaculada Serrano
}

\section{Abstract}

Displaced persons are relevant actors in determining not only some of their life options but also some of the final results of violent conflict and policies addressing such conflict. Patterns of relocation and return are a key part of those results, especially ethnic-related conflicts. An introductory model to the micro foundations of return (and relocation) is presented here. This model is intended to provide tools for a better understanding of the way violence affects individuals, and more concretely of the way individuals react and cope with it. Particular emphasis is given here to the role played by security concerns (originating in the conflict) in the decision-making process.

\section{Résumé}

Les personnes déplacées devraient être considérées comme 'acteurs qualifiés' pour décider non seulement de certains des choix qui s'offrent à elles dans la vie, mais également lorsqu'il s'agit de certains résultats finaux découlant des conflits violents et des politiques en matière de gestion des conflits. Les courants et tendances en matière de réinstallation et de retour représentent un élément essentiel de tels résultats eu égard à beaucoup de conflits contemporains, plus particulièrement les conflits d'ordre ethniques. Un modèle préliminaire sur les micro-fondements du retour (et de la réinstallation) est proposé ici, dans le but de fournir des outils pour une meilleure compréhension des effets de la violence sur les individus, et plus concrètement la manière dont les individus y réagissent et $y$ font face. L'emphase est particulièrement mise sur le rôle que jouent les préoccupations liées à la sécurité (ayant leurs origines dans le conflit) dans le processus décisionnel.

\section{Introduction}

When talking about refugees and persons who are displaced as a result of violent conflict, we are implying a double disruption in people's lives. On the one hand, violence has erupted into their lives and it has become a major force shaping them. On the other hand, they have been forced to leave their homes, which in many cases means they are no longer able to lead the kind of life they led before.

Refugees ${ }^{1}$ have had their lives affected in a most dramatic way by "politics by other means." ${ }^{2}$ And they continue to have it, as long as their available life options continue to be conditioned by the scenarios of conflict settlement and resolution, the actual peacekeeping, peacemaking, and peacebuilding strategies and interventions, the available humanitarian assistance and the international and local refugee regimes.

Having this in mind should lead to a profound reflection about the hierarchy of concerns present in the policies addressing "politics by other means." Are the rights and lives of over 30 million persons the primary concern? ${ }^{3}$ Do questions of political interests, political pragmatism, or political idealism come first? Must they?

Apart from such reflections, the recognition of refugees as persons whose life options have been overwhelmed by political designs and developments should also draw attention to the way these persons not only are affected by these developments, but also to the way they react to them and cope with their situation. In doing so, they become (and should be considered) relevant actors in determining not only some of their life options, but also some of the final results of "politics by other means" and policies addressing them. It is relevant, then, not only from a humanitarian point of view, to interrogate ourselves about the way violence (and the threat of violence) impacts individuals and groups. And, more specifically, to interrogate ourselves about the way individuals and groups cope with it and react to it. 


\section{Looking at Return from the Micro Level}

There is no doubt that the relocation process unchained by the conflict is the one aspect in which refugees are probably most conditioned and limited by the both policies and "politics by other means. Not only because of the original forced movement, but also regarding where and how they (may) end up, either temporarily or on a more permanent basis. Freedom of movement is usually hampered for most refugees and displaced persons, either in a formalized way or in an effective way, subject to different asylum regimes, refugee centres' regulations, rampant insecurity, or a stark lack of resources and livelihood alternatives as a result of war and displacement. ${ }^{4}$ Obviously, policies and "politics by other means" have a major say as well in preventing, facilitating, or pushing the reversal of the original move. However, not all the variation found in the patterns of return and relocation can be explained through such macro factors. Otherwise it would be hard to explain the variable rates and patterns of return between locations most similar in their background and structural features, such as the municipalities of Zvornik and Vlasenica in Bosnia-Herzegovina, for instance. ${ }^{5}$ In order to understand what is involved in such a process, we need to look at the micro level and understand the social processes and mechanisms unchained by political violence.

\section{Micro Foundations for Return}

We tend to assume the return to the place of origin, from which people were forced to leave, as a natural move. And there are sound reasons for this. ${ }^{6}$ Firstly, there are the illegitimacy of the reason that pushed the fleeing, the brutality and violation of human rights involved, and the injustices generated in the process. ${ }^{7}$ The restoration of the situation, reversing what was done, is therefore perceived as a matter of justice and rightness. Secondly, it may be assumed that when fleeing, the individual was forced to leave behind assets, investments, and livelihood in which her welfare was sustained, including house, land, and businesses. For many, the repossession of such assets and investments may remain crucial, given that the scenario of displacement is often a scenario of impoverishment and helplessness. ${ }^{8}$ And in many cases the repossession makes no economic sense if not moving back (e.g. given difficulties of selling the property and getting an appropriate revenue from it). Lastly, but not less importantly, it remains the recognition of a deep intimate and unique connection with the place of origin, that is, with the place which is considered to be "home."

However, the case is more complex than that, and all the latter assumptions must be carefully considered. Regarding the restoration or the reversal of the wrong done, the case is often not as simple as "moving back." Both the current situation and also the original one may be far from ideal, and moving back may do little (or even work contrary) to the interest of justice and restoration of rightness. ${ }^{9}$ The movement of return may not be a solution by itself to those issues.

Also, the case of assets and investments is not clear, as they may not exist or may not be relevant enough. They may also have been destroyed or taken away. Or there may be too many obstacles in the way to repossess them (and/or to exploit them), such as property issues, widespread discrimination, overcharges in taxes or fees, etc. Furthermore, the individual may have developed opportunities, obtained assets, or realized investments when in displacement. The very scenario of displacement may be relatively more advantageous in terms of economic and welfare opportunities.

Finally, the utter strength of the link between the displaced person and her place of origin should also be considered more carefully. In the first place, such a connection may have not existed (as ideally imagined) to begin with, ${ }^{10}$ apart from the individual cases of those who for some reason disliked or repudiated their particular places, or just felt unhappy or uprooted there ${ }^{11}$ as well as those who did not have clear roots or did have multiple ones (i.e. because of changing places during childhood and/or adulthood). This can amount also to a cultural or collective issue, as showed in in-depth field research conducted in the Horn of Africa. ${ }^{12}$ Such research revealed that these peoples, with a history of displacement and geographical mobility, did not perceive themselves as bound to a particular place. Cases are not uncommon either in which violent conflict itself and the transformations of the place of origin have estranged it from the individual: "How can it be assumed that refugees are returning 'home' when the very reason they left were that they did not feel 'at home' anymore? [...] This is particularly true in the context of civil wars, ethnic and religious conflicts." 13 There are many cases in which displaced persons have "no reason to return" and they do not return even when security concerns no longer exist. ${ }^{14}$ Furthermore, the individual may have developed new connections during displacement with the place and the people there $^{15}$ that might compete with the old ones, especially if the latter were weak or have been severed, as just mentioned. This could be expected especially in the case of long-term displacements, mostly in those cases with a highly entrenched conflict (thus leaving few expectations for return and pushing people into a new direction due to the virtual elimination of such possibility). ${ }^{16}$ And also for those living under the most normalized circumstances instead of being circumscribed, for instance, to a highly restrictive environment, as it is the case in many refugee camps and collective centres or under certain asylum regimes. ${ }^{17}$ 


\section{The End of Violence}

There is furthermore one more crucial issue that renders return a complex, far from straightforward, option. And that is the very same reason why people left in the first place: the risk assumed by being there. Obviously, the case is clear-cut when the violence is still going on, but it applies to other cases as well. Even when peace may appear stable (for instance, after the signing of a peace agreement, after the deployment of peacekeeping troops or after the occurrence of a disarmament process ${ }^{18}$ ), still there are chances in most scenarios that instability may regain momentum and violence may recur. ${ }^{19}$ In general, even for experts, it is hard to assess and assert the end of violence in a definite way. ${ }^{20}$ Thus, it is not only violence, but the threat of violence and the shadow that sheds over people which matters. As a matter of fact, there is always room for thinking that, if not in the short term, violence can eventually resume in the middle or longer term. The consideration of such a risk seems the more compelling since we are dealing with people who have undergone the experience of violence. Given such experience we could expect that credibility of peace as a dominant situation in the state of the world and credibility of commitments to peace by other actors have been severed. Indeed, if these people fled, it was because the bond of trust between them and their place of origin was broken at a certain point. ${ }^{21}$ What matters the most in this case is the individual's perception of such threat.

The intriguing and complex nature of return (in terms of security) can be best observed through the lenses of rational choice. It is difficult to question the rationality of the decision to flee in order to secure one's survival and physical integrity. ${ }^{22}$ The decision to return is precisely the one that does not look so rational a priori. For a better grasp of this idea, it is useful to assume the most simplified scenario possible, where the individual has fled an unsafe area and has reached a safe one. ${ }^{23}$ If this is the case, there is no benefit to be expected (in terms of security) from moving back. This is even the case when the threat has been also removed in the place of origin, as there is no relative advantage to be derived from it.

\section{Ongoing Research Project}

The four elements mentioned so far as the pillars for the assessment and understanding of return (and no return), namely, justice, welfare, roots, and security, are part of a doctoral research project currently being undertaken in Bosnia-Herzegovina. ${ }^{24}$ While considering the importance and relevant roles of all of them, my personal and academic interests lay specifically in the latter two: firstly, the extended shadow left by violence in the form of continued threat, the perception of such threat and the concern about it; and not less importantly, the analysis and understanding of the con- nection with the place considered "home" (what might be called "pulling effect of the home origin"), ${ }^{25}$ and the way such a connection is affected by the strain of violence. =I will devote the remaining part of this article to the security component.

The research question trying to be answered is, put simply: why do individuals move back after being displaced because of a serious threat of violence? First of all, why do some persons (under similar conditions) return and others do not? But secondly, and most interestingly, as following the security puzzle: why do the former return at all, given that they are displaced within a safe area in which their security is not under strain, as it was in their place of origin? ${ }^{26}$ Why (and under what conditions) do individuals who have demonstrated their aversion to the threat of violence take the step of coming back?

\section{The Security Component}

As already noted, threat is a matter of perception (belief), as well as a matter of analysis. And as such it is a cornerstone issue for return. However, little is known of the way threat is evaluated and incorporated into the decision-making process. Two basic considerations must be taken into account: the fact that displaced persons have already been subject to a serious threat of violence (if not to serious violence itself), and the circumstance that they are away from the scenario which is being evaluated. ${ }^{27}$ The questions following this proposal are two: firstly, how do persons who have experienced the effects of violence measure and perceive the current and future threat of similar violence (without even being present in the actual scenario)? And secondly, how does it affect the decision of return?

\section{Perception and Measurement of the Threat}

There are three key elements to take into account. The first obvious element is the actual threat. The nature and shape of the threat (that is, the nature of conflict and the shape of violence) logically determine the way in which it is to be evaluated: what factors are to be considered, whether it is more or less feasible to monitor them, etc. ${ }^{28}$ The second element is imperfect information, which is the more accentuated having taken into account the distance between the person and the object of evaluation. In most cases such evaluation will be highly mediated by different sources of information, which may introduce further biases. The third element is emotions, with special attention given to fear.

The perceived threat will likely emphasize some aspects of the "objective scenario" over others; it may also neglect some or clearly depart from others. Those aspects that differ clearly and most regularly are likely to be the result of imperfect information and of the intervention of emotions. 


\section{Figure 1. Perceived Threat}

Real threat $*$ imperfect information $*$ emotions $=$ perceived threat

The following categorization of the different kinds of (real) possible threats has been derived from the empirical observation of the universe of cases producing or maintaining IDPs during the year 2002.
The sources of threat causing displacement (and being evaluated upon return) have been categorized as follows:

A. Foreign political-military force (i.e. border conflict). Individuals fled conventional "interstate" warfare (between armies) affecting civilians. The situation may remain unstable or the foreign power may be in control of the area. The threat may include communal violence.

B. Crossfire between Government Troops and Armed Groups (i.e. factions, rebel groups). Individuals fled generalized

Table 1. Nature of the threat

(in conflicts generating or maintaining IDPs in 2002)

Features proposed as having implications for the evaluation of the threat

\begin{tabular}{|c|c|c|c|c|c|}
\hline SOURCE & $\begin{array}{l}\text { Foreign } \\
\text { Power }\end{array}$ & $\begin{array}{l}\text { Armed } \\
\text { Groups }\end{array}$ & $\begin{array}{l}\text { Gov. and } \\
\text { armed } \\
\text { groups }\end{array}$ & $\begin{array}{c}\text { Gov. and armed groups } \\
\text { in separatist/ } \\
\text { minority area }\end{array}$ & $\begin{array}{c}\text { Communal } \\
\text { Violence }\end{array}$ \\
\hline $\begin{array}{l}\text { NATURE OF } \\
\text { THE SOURCE }\end{array}$ & \multicolumn{4}{|l|}{ Organised actors } & Dispersed \\
\hline \multirow[t]{2}{*}{ TARGET $\dagger$} & $\begin{array}{l}\text { Not civilians, } \\
\text { still affected }\end{array}$ & \multicolumn{2}{|l|}{ Civilians targetted } & \multicolumn{2}{|l|}{ Ascriptive groups targetted } \\
\hline & $\begin{array}{l}\text { Eritrea-Ethiopia } \\
\text { Armenia-Azerbaijan } \\
\text { Cyprus } \\
\text { Israel } \\
\text { Lebanon } \\
\text { Syria (Golan Heights) }\end{array}$ & $\begin{array}{l}\text { Algeria } \\
\text { Angola } \\
\text { DRCongo } \\
\text { Liberia } \\
\text { SLeone } \\
\text { G-Bissau } \\
\text { Colombia } \\
\text { Peru } \\
\text { Philippines }{ }^{\star *} \\
\\
\text { Ethnicity underlying } \\
\text { Burundi } \\
\text { RCongo } \\
\text { Sudan } \\
\text { Guatemala } \\
\text { Mexico } \\
\text { Afghanistan } \\
\text { Serbia South } \\
\text { Macedonia }\end{array}$ & $\begin{array}{l}\text { G-Conakry } \\
\text { Uganda (east) } \\
\text { Iraqi Kurdistan } \\
\text { Ethnicity underlying } \\
\text { Uganda (north, west) } \\
\text { Rwanda } \\
\text { Somalia }\end{array}$ & $\begin{array}{l}\text { Homogeneous area } \\
\text { Burma } \\
\text { Sri Lanka } \\
\text { Turkish Kurdistan } \\
\\
\text { Majority group in a } \\
\text { mixed area } \\
\text { SenegalCasamance } \\
\text { Bangladesh CHT } \\
\text { India Kashmir } \\
\text { Indonesia Aceh } \\
\text { Georgia Abkhazia } \\
\text { Russia Chechnya } \\
\text { Moldova } \\
\text { Transdniestrian } \\
\\
\text { Minority group in a } \\
\text { mixed area } \\
\text { SenegalCasamance } \\
\text { Bangladesh CHT } \\
\text { India Kashmir } \\
\text { Indonesia Aceh } \\
\text { Georgia Abkhazia } \\
\text { Russia Chechnya } \\
\text { Moldova } \\
\text { Transdniestrian }\end{array}$ & $\begin{array}{l}\text { Kenya } \\
\text { Nigeria } \\
\text { India (Gujarati) } \\
\text { Indonesia (Malukus, } \\
\text { Kalimatan) } \\
\text { Solomon Islands } \\
\text { Georgia (Ossetia) } \\
\text { Russia (Ossetia) } \\
\\
\text { Armed groups } \\
\text { significant } \\
\text { India (north-east) } \\
\text { Indonesia (Sulawesi) } \\
\text { Bosnia } \\
\text { Croatia } \\
\text { Serbia (Kosovo) }\end{array}$ \\
\hline
\end{tabular}

$\uparrow$ Matching between source and target categories corresponds to the empirical observations of the cases considered. No necessary or exhaustive connections are implied here.

*Also displacement for ethnic-violence

**Also separatist component

Sources: Global IDP Project, World Refugee Survey, International Crisis Group 
violence targeting all civilians in the country or region. The threat arises from each of the sides (also the government).

(2) with ethnic cleavages underlying. They fled generalised violence targeting all civilians, but the threat of violence increases (to varying degrees) with ethnic ascription.

C. Fire from Armed Groups. They fled violence targeting all civilians. The threat arises from armed groups acting against the government and/or the population, or fighting each other (i.e. government is weak or non-existent).

(2) with ethnic cleavages underlying. They fled violence trapping/targeting all civilians, but the threat of violence increases (to varying degrees) with ethnic ascription.

D. Crossfire between Government Troops and Armed Groups in Separatist/Minority Areas.

(1) Homogenous area. They fled violence targeting their ethnic group by the government, and more generally violence trapping all civilians (also by the armed groups).

(2) Majority in the area. They fled violence targeting their ethnic group by the government, and more generally violence trapping all civilians (also by armed groups). It may include communal violence from the minority group in the area.

(3) Minority in the area. They fled violence targeting their ethnic group by armed groups, and it may include communal violence.

E. Communal Violence. They fled violence targeting their ethnic group. The threat arises from members of different ethnic groups. The threat usually includes armed groups.

The evaluation (and hence the perception) of the threat is a function of the different factors implied in the nature of threat. If we understand the perception of the threat as the perceived odds of being hit by violence, ${ }^{29}$ the components of that calculation in each case are likely to be the following:

A. Foreign political-military force (border conflict).

$F$ (intensity conflict + communal violence)

B. Crossfire between government troops and armed groups (factions, rebel groups).

$F$ (intensity conflict + intensity abuses government* personal saliency ${ }^{30}$

+ intensity abuses armed groups ${ }^{\star}$ personal saliency)

(2) with ethnic cleavages underlying

$F$ (intensity conflict + intensity abuses government ${ }^{*}$ ethnic ascription ${ }^{\star}$ p.saliency + intensity abuses armed groups $^{*}$ ethnic ascription ${ }^{\star}$ p.saliency)

C. Fire from armed groups

$F$ (intensity abuses armed groups ${ }^{\star}$ personal saliency)
(2) with ethnic cleavages underlying.

$F$ (intensity abuses armed groups ${ }^{\star}$ ethnic ascription ${ }^{\star}$ personal saliency)

D. Crossfire between government troops and armed groups in separatist/minority areas.

(1) Homogenous area.

$F$ (intensity conflict + intensity abuses government ${ }^{*}$ personal saliency

+ intensity abuses armed group ${ }^{*}$ personal saliency)

(2) Majority in the area.

$F$ (intensity conflict + intensity abuses government ${ }^{*}$ personal saliency

+ intensity abuses armed group ${ }^{\star}$ personal saliency

+ communal violence)

(3) Minority in the area.

$F$ (intensity conflict + intensity abuses armed group ${ }^{\star}$ personal saliency

+ communal violence)

E. Communal violence.

$F$ (communal violence + intensity abuse armed groups $^{*}$ personal saliency)

Naturally, other factors affecting security assessment, though not that dependent on the particularities of the threat, are missing in this analysis and should be taken into account. $^{31}$

Each kind of threat and each factor within it can be broken down and conceptualized in a systematic manner, and subsequently translated into indicators adequate for each country and conflict. The appraisal of all these factors by the individual, nonetheless, will, it is expected, be mediated by the intervention of emotions and the absence of perfect information. Such mechanisms must be detailed and introduced in the model as well.

For instance, in all the cases, except those of communal violence, the threat arises from concrete (organized) actors. The removal of such source of threat is relatively easy to identify through the defeat, disappearance, or agreement of the actors in conflict, and relatively easy to assess and monitor (whether it is present in the area or not, its relative strength, etc.) ${ }^{32}$ The sides of the conflict may either have disappeared: rebels may have been annihilated or jailed, or they may have fled, governments may be deposed. Or they may be diluted in the post-conflict society: rebels may be disarmed or reintegrated, ${ }^{33}$ and governments may undergo reforms and political agreements. ${ }^{34}$ Even when these actors, which were the source of the threat, remain (more or less diluted) in the society, their direct position as a source of threat is put somewhat under strain, as some organizational or political developments should be expected for them to resume such position. 
On the contrary, in cases of communal violence, where the threat arises from ethnic ascription, the source of the threat is dispersed. It is difficult to identify and to monitor, what means that mistrust and fear are generally extended to a complete category of individuals, whether it is personally reasonable or not. The specific ways in which individuals measure and assess such a threat remain intriguing and deserve special attention. The main mechanisms I propose for the case of Bosnia-Herzegovina are based on the perception of the distribution of hard-liners in the area of return and the amount of resources (including political ones) that they command, as well as on the numbers and characteristics of returnees in the area (safety in numbers argument) and the actual occurrence of episodes of violence. The perception of all these factors is mediated, on the one hand, by the information (and opinions) provided by social contacts from the place of origin (both earlier returnees and other displaced people visiting the area or discussing the issue). And their perception is mediated as well, on the other hand, by the presence of different emotions, with a special relevance given to fear. Emotions are incorporated into the model as an exogenous input consisting of a specific kind of information (i.e. they provide the individual with information about her preferences and her relation to the world and its changing stimuli). ${ }^{35}$

\section{Incorporation of the Threat into Decision Making}

My claim is that all factors and mechanisms related to the security component are enabling factors of the decision to return. They do not constitute explaining factors of return.

As already noted, once the individual is in a safe area, the removal of the threat is not a motive to return per se, as it does not provide any comparative advantage. It only constitutes the removal of the main impediment to move back. What must explain return are pulling factors in the home origin (and pushing factors in displacement), which in some cases are strong enough as to overcome the persistence of threat, or the existence of other pulling factors in displacement. I already mentioned the three main factors: justice, welfare, and roots.

Figure 2 offers a graphic summary of the components of the decision to return. There are factors related to justice, welfare, and roots that tie to the place of origin, but there may be others as well, in all the three dimensions, working just on the contrary direction. The same happens with the location of displacement. The consideration of all these factors is conditioned, however, to the barrier of insecurity to be broken. This remains a matter of grade, given that the assessment of violence (and future violence) is somehow elusive. The minimum level of security that is required in order to pass that barrier will depend on the relative
Figure 2. Enabling Factors and Explaining Factors of Return (and No Return)

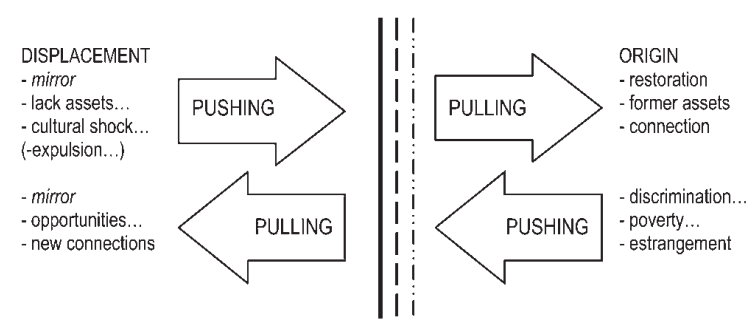

strength of the pulling effect of the home origin, as well as the factors pushing to abandon displacement.

"Happy dilemmas" are the very rare cases in which the pulling factors dominate for both return and relocation. These are people who have found a new promising life in displacement, but still have plenty of reasons (and emotional drive) for longing for their home origin. Much more common, unfortunately, are the cases where the pushing factors dominate, that is, where people seem to have no place to stay and no place to go back to. Elderly people are the ones usually having both arrows pointing to return: they cannot adapt that easily or find a place for themselves in the new reality, and they have a whole life of investments (both material and emotional) back in their place of origin. Youngsters tend to present just the contrary case, especially when they have moved from a rural to an urban area.

\section{Notes}

1. I will use interchangeably the terms "refugees" and "displaced persons" and I will be referring to the whole category of persons who have been forced out of their homes because of a violent conflict, no matter whether they have crossed an international border or not, or whether they fit into the Convention definition.

2. This is Clausewitz's well-known definition of war. Karl von Clausewitz, On War (Harmondsworth: Penguin Books, 1873).

3. UNHCR recognizes 12.7 million refugees under the Convention definition (including Palestinian numbers) and around 1.2 million asylum seekers and other persons of concern (not counting stateless persons); see 2005 Global Refugee Trends. The Global IDP Project of the Norwegian Refugee Council estimates 23.7 millions of internally displaced persons (IDPs); see the latest data and statistics in http://www.IDPProject.org. The World Refugee Survey 2006 of the US Committee for Refugees and Immigrants records 12 million refugees and 21 million internally displaced people. the survey is available at $<$ http://www.refugees.org $>$. 
4. In the year 2005 there were 7.89 million refugees who had been already warehoused for five years or more. US Committee for Refugees and Immigrants, World Refugee Survey 2006, $<$ http://www.refugees.org/data/wrs/06/docs/key_statistics.pdf $>$ (accessed September 30, 2006).

5. Located in the eastern part of the Republic of Srpska, in Bosnia-Herzegovina, both of them were Muslim-majority areas (above 50 per cent of the population) before the war, with very similar social and economic structures. Both suffered a fierce campaign during 1992 and remained under Serb control until the end of the war. Both municipalities received a massive influx of Serb refugees and both have been dominated after the war by hard-line nationalists. However, Zvornik has registered some of the earliest movements of minority returns (1996) and the highest rates of total returns in the whole country. Vlasenica, on the other hand, has been the last municipality opening the process of return (2000) and it has registered the lowest rates of total minority returns so far. These data have been gathered and confirmed through the fieldwork conducted in the last year in the region and they form part of my forthcoming doctoral dissertation project. For the absolute numbers of minority returns in each municipality, see UNHCR, Map Total Minority Returns, available at <http:// www.unhcr.ba/return/pdf\%202006/SP_07_2006.pdf> (accessed April 9, 2008).

6. Since the 1980 s, voluntary repatriation has been promoted by governments and UN agencies as the desirable and ultimate solution to refugees. However it seems clear that strategic considerations are likely to be behind such policy. See Tania Ghanem, "When Forced Migrants Return 'Home': The Psychosocial Difficulties Returnees Encounter in the Reintegration Process," (RSC Working Paper No. 16, Refugee Studies Centre, University of Oxford, 2003).

7. "Not only do most African refugees perceive their involuntary displacement as temporary but also return is considered as a great success. Return to the place one has been violently uprooted from is an overriding preoccupation, bordering obsession, of most refugee populations in Africa. This is not only true in Africa." Gaim Kibreab, "Revisiting the Debate on People, Place, Identity and Displacement," Journal of Refugee Studies 12 (1999): 384-410.

8. See for instance Awa M. Abdi, "In Limbo: Dependency, Insecurity, and Identity amongst Somali Refugees in Dadaab Camps," Refuge 22, no. 2 (2005): 6-14.

9. For instance, in many places in Bosnia-Herzegovina the scenario of return is not a welcoming one. This is so because of episodes of harassment, which were frequent and often lifethreatening at the beginning of the process, generalized discrimination, and lack of infrastructure in many of the return areas. In such a situation, it turns out that the ones returning are often the least advantaged, who return as a result of lack of alternatives. And they are left facing a situation of marginalization and mistreatment.
10. Madawi Al-Rasheed, "The Myth of Return: Iraqi Arab and Assyrian Refugees in London," Journal of Refugee Studies 7, no. 2-3 (1999):199-219.

11. Ghanem.

12. UNRISD symposia, quoted in Ghanem.

13. Íbid., 21-22.

14. See Global IDP Project, Internally Displaced People: A Global Survey, (London: Earthscan, 2002).

15. For instance, by forming a family and upbringing the children in the new context. See Ghanem.

16. There are cases, like the Palestinians, which clearly challenge this hypothesis.

17. See Refuge 22, no.2 (2005).

18. For an analysis of the credibility and effectiveness of peace agreements see William Long and Peter Brecke, War and Reconciliation: Reason and Emotion in Conflict Resolution (Cambridge, MA: Massachussetts Institute of Technology Press, 2003).

19. The defeat of one side or the signing of an effective peace agreement may occur, but violence may be later resumed or some other faction may take it up, as in the cases of Mindanao (Philippines), or Burundi. Violence may be recurrent (especially in cases of communal violence as riots) or even cyclical, as exemplified by conflict in the Republic of Congo (Brazzaville), in separatist Aceh (Indonesia), or Casamance (Senegal). Some conflicts have a "chronic" character of generalized violence, as in Colombia. As in Angola, violence may decrease during some periods or in specific areas without the conflict and violence being ended or solved. There are cases in which the ending of violence may be quite clear, but some more or less sporadic violence may still occur, as in the cases of Bosnia, Sri Lanka, or the Transdniestrian region in Moldova.

20. The huge literature on conflict management, conflict resolution, and early warning systems is testimony of that.

21. Ghanem.

22. Indeed, this is one of the most recurrent arguments by those who defend the functionality and "covered" rationality of emotions: fear makes you take the right decisions in the right moment, normally fighting back or fleeing. See Antonio Damasio, Descartes' Error: Emotion, Reason, and the Human Brain (New York: Putnam, 1994).

23. The assumption that the context of displacement is safe and that security is not under strain (to the same extent and in the same manner as it was in the place of origin) does not apply in many cases, especially for internally displaced people or people displaced into neighbouring countries, who often find themselves in a situation of vulnerability and exposure. For instance, IDP camps and "protected villages" have constituted for years the most regular targets for the Lord's Resistance Army (LRA) attacks in Uganda's Ruwenzori Mountains. See Global IDP Survey 2002. In a recent document elaborated by different international NGOs and incorporated into the World Refugee Survey 2006, special attention is reclaimed for warehoused refugee women, denouncing a "myriad of human rights violations against displaced women and girls during all 
stages of displacement," including sexual exploitation and involuntary recruitment into militia and armed forces, abduction and trafficking, as well as lack of access to humanitarian assistance.

24. Many of the reflections, examples, and details presented in this article are derived from that work and from the experience of Bosnia-Herzegovina.

25. This means digging into the question of the sources of (deeply rooted) local attachments, which are at the base of nationalisms, regionalisms, and localisms, and which lie at the heart of the exile nostalgia and other like phenomena.

26. By "safe area" I understand an area where violence is not a pervasive threat for the individual. As I already noted, this is not usually the case. So far, I have just focused on cases fulfilling such a condition, simplifying the puzzle as much a possible for clarity, with the number of factors intervening kept as low as possible. However, research should continue in this direction.

27. Though cases vary in the possibility, frequency, and intensity of visits and stays in the area.

28. The nature of the threat will have major consequences for the process of return, not only in this regard, but also when considering the kind of conflict they are linked to (either warlords' factions, communal ethnic violence, conventional interstate warfare, etc.) and the kind of marks left upon society (level and targets of destruction, number and characteristics of human losses, etc.).

29. This implies a certain homogenization of violence, as far as aversion to violence is concerned.

30. This should be defined by the usual and logical targets of the source of violence. The characteristics which may raise the saliency of individuals as a target range from social, professional, or ideological visibility (e.g. local leaders, journalists) to personal characteristics which render them more vulnerable or more attractive as a target (e.g. women, children used as soldiers, wealthy persons abducted).
31. Like the presence of landmines, the availability of an effective exit option (i.e. distance to the border), the visibility of the return area (i.e. remote rural areas), the presence of international forces, and so.

32. For instance, in April 2000 Chechen fighters were reported to have withdrawn from the lowlands to consolidate in the mountains. Then, some return movements occurred. See Global IDP Survey 2002. See also Long and Brecke for an analysis of the credibility and effectiveness of peace agreements.

33. Forty-five thousand former fighters in Sierra Leone had handed in their weapons by January 2002, marking a substantial improvement in the security situation in the country. In Angola, UNITA soldiers and their families congregated at more than forty sites throughout the country in 2002 to disarm and begin the process of demobilization. The government army accepted 5,000 UNITA soldiers into its own ranks. Observers expressed concern that thousands of UNITA weapons might remain hidden, but a general climate of optimism prevailed (World Refugee Survey 2002).

34. As in Burundi (2001), Macedonia (2001), or Bangladesh (1997).

35. See Damasio; Roger Petersen, Resistance and Rebellion (Cambridge: Cambridge University Press, 2001); Yaniv Hanoch, "Emotions as a Mechanism for Boundedly Rational Agents," communication at the IV Winter Workshop on Economics and Philosophy: Psychological Foundations of the Theory of Choice in Economics (Madrid: UNED, 2003).

Inmaculada Serrano Sanguilinda is a PhD candidate in the Institute Juan March in Madrid and the Department of Political Science at the Universidad Autónoma de Madrid. 